\title{
Fruit Phenology of Tree Species and Chimpanzees' Choice of Consumption in Kalinzu Forest Reserve, Uganda
}

\author{
Grace Kagoro-Rugunda1, Chie Hashimoto ${ }^{2}$ \\ ${ }^{1}$ Department of Biology, Mbarara University of Science and Technology, Mbarara, Uganda \\ ${ }^{2}$ Pimate Research Institute, Kyoto University, Inuyama, Aichi, Japan \\ Email: kgraceug2002@yahoo.co.uk, hashimoto@pri.kyoto-u.ac.jp
}

Received 29 January 2015; accepted 6 October 2015; published 9 October 2015

Copyright (C) 2015 by authors and Scientific Research Publishing Inc.

This work is licensed under the Creative Commons Attribution International License (CC BY). http://creativecommons.org/licenses/by/4.0/

(c) (7) Open Access

\begin{abstract}
One hundred and eighteen (118) tree species were identified, among which 58 species produced fruit within the two-year study. Fruit of only $26.3 \%$ of the latter is eaten by chimpanzees. The consumption of each of these fruits was generally low, with only two species constituting more than $25 \%$ consumption. Only about $1.7 \%$ of woody biomass is relied upon by chimpanzees in Kalinzu for food. The major tree species in chimpanzee diet monitored showed that fruit production varies monthly and seasonally. Apart from Musanga leo-errerae and Ficus spp. whose fruiting was consistent throughout the year, general fruit phenology was positively correlated with rainfall. Only three species namely: Craterispermum laurinum, Aframomum angustifolium and Beilschmiedia ugandensis produced fruit in the dry seasons. Correlation between fruit availability and consumption was significantly positive for only one species, Landlophia dawei. This indicated that frugivory of chimpanzees in Kalinzu was not opportunistic; they search for what they like to eat. Chimpanzees would have to range furthest in periods of scarcity and asynchronous fruiting hence a lot of energy expenditure in the food search alone. Therefore, diversity in fruit phenology is important for chimpanzees' energy conservation, health and survival. Selective logging and other selective human activities that involve cutting down trees that are palatable would in future affect the food diversity and consequently the health of frugivores if not done sustainably. Since patterns of fruit phenology are also linked to patterns of rainfall, changes in the former can assist in predicting the influence of climate change on food availability for big frugivores like chimpanzees.
\end{abstract}

\section{Keywords}

Chimpanzees, Consumption, Fruit, Kalinzu, Phenology 


\section{Introduction}

Knowing the dynamics of fruit production is important for understanding great apes' (chimpanzees, gorillas, and bonobos) ecology, as fruit provides a nutritious resource for most of them in tropical African regions. Plant species composition, density, distribution and temporal fluctuation affect apes' ecological features such as diet [1]-[5], ranging patterns [6]-[8], group size [9] [10], reproductive parameters [11], patterns of social interaction [12] and tool-using behavior [13]. Comparison of fruit phenology is also important for understanding the ecological differences in great apes among different study sites. The patterns of fluctuation in party size of chimpanzees are different among four chimpanzee study sites and it was suggested that the differences in dynamics of fruit production among sites were the cause [9]. The annual and seasonal fluctuations in fruit production are distinct, and a period of fruit scarcity exists at all study sites [14]. In Central Africa, fruits are more abundant in the rainy season than in the dry season. In Lopé National Park (Gabon), fruit abundance peaks in the early rainy season and fruits are scarce during the long dry seasons. Fruit abundance peaks may also occur during the mid-rainy season and become scarce during the dry season [2] [6] [15]. In East Africa, climatic factors influencing fruit phenology are varied among sites. In Mahale Mountains National Park (Tanzania), the number of plant species in fruit declines in December, January and February during the rainy season [16]. In Kibale Forest (Uganda) and Kahuzi-Biega (DRC) National Parks, fruit abundance is negatively correlated with monthly rainfall, and more fruits are available during the dry season [8] [17]. In contrast, peaks in fruit abundance occur during the rainy season in Budongo [18]. In the two sites of West Africa, Taï National Park (Cotê d'Ivore) and Bossou (Guinea), fruits tend to be abundant during the dry season [13] [19]. Even within the same habitat, patterns of fruit production differ among species, plant life forms, and vegetation types, and therefore periods of fruit scarcity also vary.

Frugivorous animals respond to periods of fruit scarcity by changing their dietary composition and/or ranging patterns [6] [8] [14] [20]. Several primate populations like vervet monkeys (Cercopithecus aethiops) [21] and baboons (Papio anubis) in Amboselli, Kenya, and Toque macaques in Sri Lanka [22] have been documented to decline in number with a natural decline in their food resources. In Kalinzu forest, selective commercial logging and pit sawing continue to occur, especially in the eastern part [23] [24]. The former Nkombe saw mill, a logging company, had been mechanically logging in the north eastern part of the forest and exclusively harvested Parinari excelsa. Local people have been harvesting/logging some useful trees, such as Carapa grandiflora and Funtumia africana, in some areas. These logging activities created some patches of secondary vegetation.

Phenological patterns are linked to factors that govern forest health such as population biology of pollinators, seed dispersers and predators, herbivores, interspecific competition among trees and other processes of primary production [25] and assist conservation scientists in predicting consequences of adverse climatic events. In this paper, overall fruit abundance and patterns of fruiting of major species are analyzed in relation to rainfall and chimpanzee feeding patterns. This will provide baseline data for management options occurring in Kalinzu Forest Reserve especially during periods of tree harvests and habitat-wide fruit scarcity since this has a dietary implication on population dynamics of frugivores like chimpanzees.

\section{Study Area}

In Uganda, chimpanzees are restricted to the western part and the total number is estimated at 4950 . Of these, 230 occur in Kalinzu at a density of $1.55 \mathrm{~km}^{-2}$ ranking third after Kibale at $2.32 \mathrm{~km}^{-2}$ and Bugoma at $1.9 \mathrm{~km}^{-2}$ (Table 1) [26]. Kalinzu Forest Reserve lies in south-western Uganda ( $0^{\circ} 17^{\prime} \mathrm{S}$ and $\left.30^{\circ} 07^{\prime} \mathrm{E}\right)$. It covers $137 \mathrm{~km}^{2}$ and borders the Maramaganbo forest and the two form part of the Queen Elizabeth National Park. Kalinzu forest is one of the richest forests in Uganda, with more tree species recorded here than anywhere else. Three important timber species from this forest are considered endangered. These include Cordia milleni, Entandrophragma angolense, and Lovoa swynnertonii [27]. It is inhabited by six species of primates including the largest population of l'hoest's monkeys (Cercopithecus l'hoest), a species considered vulnerable to extinction. Kalinzu together with Maramagambo forests represent the largest tract of forests at this altitude in Uganda. Kalinzu covers an exceptional altitudinal range, which combined with its topographical, climatic and geological diversity, and its location in western Albertine rift valley close to the believed upper Pleistocene forest refugia, gives rise to a great variety of forest habitat. The Forest occupies a shallow saucer-shaped depression in the rift valley escarpment with its floor at about $1463 \mathrm{~m}$ above sea level from which rise a few grassy hills that reach up to $1845 \mathrm{~m}$.

The vegetation of Kalinzu is broadly classified as medium altitude moist evergreen tropical rain forest [27]. 
Table 1. Ugandan forests inhabited by chimpanzees (NP—national park; FR—forest reserve).

\begin{tabular}{ccccc}
\hline Forest & Size $\left.\mathbf{( k m}^{\mathbf{2}}\right)$ & $\begin{array}{c}\text { No. of tree species } \\
\text { (\% of country total species) }\end{array}$ & Total chimpanzee population & Density of chimpanzees \\
\hline Kibale NP & 795 & $209(49 \%)$ & 1420 & 2.32 \\
Bugoma FR & 365 & $158(36 \%)$ & 630 & 1.90 \\
Kalinzu FR & 137 & $265(57 \%)$ & 230 & 1.55 \\
Budongo FR & 793 & $240(56 \%)$ & 640 & 1.36 \\
Itwara FR & 97 & $143(33 \%)$ & 130 & 1.35 \\
Kasyoha-Kitomi FR & 399 & $204(47 \%)$ & 410 & 0.92 \\
Rwenzori NP & 996 & $75(18 \%)$ & 500 & 0.46 \\
Bwindi NP & 321 & $163(38 \%)$ & 210 & 0.43 \\
\hline
\end{tabular}

Generated from [26] [27].

According to the most recent classification, Kalinzu forest vegetation can be simplified into four vegetation types: mixed mature forest, Parinari dominated mature forest (Parinari mature), Parinari dominated secondary forest (Parinari secondary), and Musanga dominated secondary forest (Musanga secondary) [28]. The rainfall pattern has two peaks-in April and October. The June-July dry season is more severe than the one in January. The temperatures of Kalinzu Forest Reserve range from the minimum of $13^{\circ} \mathrm{C}$ to the maximum of $28^{\circ} \mathrm{C}$.

\section{Methods}

Ten parallel transects $5 \mathrm{~km}$ long and $5 \mathrm{~m}$ wide running east to west of Kalinzu forest were used to collect data. Distance between transects was $500 \mathrm{~m}$. Each of these transects was divided into ten $500-\mathrm{m}$ sections totalling to 100 plots. All trees above $10 \mathrm{~cm}$ in diameter at breast height (DBH) within $2.5 \mathrm{~m}$ of each side of the transect were recorded. The number of trees of each species in $5 \times 500 \mathrm{~m}$ block was used as a variable for the analysis of Species Important Value Index (SIVI). A total of $25 \mathrm{~km}^{2}$ of vegetation was sampled. SIVI values were calculated to give a comparable index incorporating measures of tree species distribution, relative density and abundance. The SIVI value is therefore, the summed value of relative density, relative frequency and relative dominance. The sum of these three values for the particular species, the species importance value index (SIVI) never exceeds 300 because each parameter is a percentage ranging from 0 to 100 [29]. Tree species were ranked on the basis of their SIVI values.

A fruit phenology census was conducted along each of these 10 transects for two years. During each census, fallen fruit was counted. Fallen fruit from one tree, $2.5 \mathrm{~m}$ of each side of the transect, was considered as one fruit cluster. When more than one tree of similar species contributed to the cluster of fruit on the ground, it was divided amongst the number of fruiting trees. The number of clusters thus matched with the number of fruiting trees that dropped fruit within the census belt. The tree species, the numbers of fruit in each cluster and whether the fruit would be ripe or unripe (determined by majority) was recorded. The numbers of fruit in each cluster was grouped as $1-4,5-9$, or $>10$, and assigned a frequency score of 1 , 3, or 9 respectively, then a fruit abundance index (FAI) was determined from the total number of scores per hectare as explained in [1]. The FAI of fruits eaten by chimpanzees was calculated separately. To examine the relationship between number of fruit in the tree and number of fallen fruit, major trees whose fruit was recorded to be eaten by chimpanzees during the preliminary faecal analysis were randomly chosen on the transects and monitored for fruit production. A record of ripe and unripe fruit was taken.

The pattern of fruit consumption by chimpanzees reported in this study was determined by faecal analysis [2]. It was supplemented by direct observations of feeding where possible, to confirm the consumption of foods that were seen in faecal sample remains. Fresh chimpanzee faecal samples were collected but those that scattered on the ground or among branches were ignored due to the difficulty in picking a representative sample of such. After a day's collection, the faecal samples were preserved in plastic bags with $100 \%$ ethanol and the following noted: date of collection, location, time of collection, and the visible contents of the faecal sample by majority constituent.

A total of 2635 faecal samples were collected in 26 months (monthly range 24 - 206; mean = 101). Each month, the faecal samples were placed in a metal sieve with $1 \mathrm{~mm}$ mesh and washed in running water. Once the 
soluble solution had gone, the seeds were sorted. The samples were then sun dried and divided into categories: seed, skin, and pulp of fruit, leaf matter, pith, ant, mammal, entire leaf, or others. We evaluated the percent volume of each food category in each sample, where the smallest unit would be $5 \%$. We recorded species names except where more than one species in the same genus could have indistinguishable seeds e.g. Ficus spp. Indistinguishable seeds in this genus were treated as a single fruit "species group". One identifiable fruit species meant one fruit species group.

\section{Results}

\subsection{Kalinzu Forest Tree Composition}

A total of 16,778 trees belonging to 118 species (6 of which remained unidentified) and 44 families were recorded. The identified tree species and their Species Importance Value Indices are as shown in Table 2. Of these

Table 2. Species important value indices, fruit availability index and consumption of fruit of tree species by chimpanzees in Kalinzu forest reserve.

\begin{tabular}{|c|c|c|c|c|c|c|c|}
\hline NAME & FAMILY & $\begin{array}{c}\text { DORMINANCE } \\
\text { Basal area/ha }\end{array}$ & $\begin{array}{c}\text { DENSITY } \\
\text { Tree/ha }\end{array}$ & $\begin{array}{c}\text { FREQ OF } \\
\text { TREES }\end{array}$ & SIVI & FAI & $\begin{array}{c}\text { \% of FAECAL } \\
\text { SAMPLES WITH } \\
\text { SEED }\end{array}$ \\
\hline${ }^{*}$ Craterispermum laurinum & Rubiaceae & $18,337.6$ & 398.9 & 3750 & 46.0 & 462.9 & 8.3 \\
\hline Funtumia Africana & Apocynaceae & $32,744.9$ & 289.7 & 2723.0 & 35.5 & & \\
\hline Strombosia scheffleri & Alocaceae & $94,377.3$ & 133.5 & 1255.0 & 24.9 & 568.1 & \\
\hline Parinari excelsa & Chrysobalanaceae & $134,656.5$ & 26.9 & 253.0 & 17.4 & 108.7 & \\
\hline${ }^{*}$ Celtis durandii & Ulmaceae & $48,255.9$ & 88.3 & 830 & 14.9 & 757.0 & 2.7 \\
\hline${ }^{*}$ Ficus spp. & Moraceae & $91,451.0$ & 31.6 & 297.0 & 13.3 & 140.2 & 67.3 \\
\hline "Musanga leo-errerae & Urticaceae & $43,269.6$ & 44.4 & 417.0 & 9.5 & 349.3 & 78.7 \\
\hline Carapa grandiflora & Meliaceae & $26,119.4$ & 50.2 & 472 & 8.4 & 97.2 & \\
\hline Sapium ellepticum & Euphobiaceae & $33,625.6$ & 39.3 & 369 & 7.9 & 178.3 & \\
\hline Carapa Procera & Meliaceae & $23,193.2$ & 38.2 & 359.0 & 6.7 & 83.3 & \\
\hline${ }^{*}$ Drypetes bipidensis & Euphorbiaceae & $28,470.2$ & 30.2 & 284 & 6.4 & 102.0 & 3.1 \\
\hline Cassipourea sp. & Rhizophoraceae & $11,386.7$ & 38.6 & 363 & 5.5 & 0.7 & \\
\hline Xymalos monospora & Monimiaceae & 9344.2 & 34.3 & 322 & 4.8 & 18.2 & \\
\hline Macaranga schweinfurthii & Euphobiaceae & 9916.5 & 34.3 & 322 & 4.8 & - & \\
\hline Oxyanthus speciosus & Rubiaceae & 3322.4 & 39.7 & 373.0 & 4.7 & 89.7 & \\
\hline "Alchonea hitera & Euphorbiaceae & 1718.1 & 39.7 & 373 & 4.6 & 118.9 & 0.1 \\
\hline Markhamia platycalyx & Bignoniaceae & $10,206.8$ & 30.5 & 287.0 & 4.5 & - & \\
\hline${ }^{*}$ Beilschmiedia ugandensis & Luauraceae & $11,847.3$ & 28.7 & 270 & 4.4 & 10.1 & 1.5 \\
\hline Trema orientalis & Ulmaceae & 8246.2 & 29.7 & 279 & 4.2 & 80.0 & \\
\hline "Syzigium guinense & Myrtaceae & $11,129.8$ & 26.9 & 253 & 4.2 & 130.2 & 0.2 \\
\hline Trichoscypha submontana & Anacardiaceae & $18,597.1$ & 16.6 & 156 & 3.8 & 131.8 & \\
\hline Newtonia buchananii & Leguminoceae & $17,644.5$ & 17.3 & 163.0 & 3.8 & 45.9 & \\
\hline${ }^{*}$ Linociera johnsonii & Caprifoliacea & 7511.2 & 24.3 & 228 & 3.5 & 43 & - \\
\hline Mitragyna stipulosa & Rubiaceae & $19,046.2$ & 10.7 & 101 & 3.2 & - & \\
\hline${ }^{*}$ Prunus africana & Rosaceae & $16,599.2$ & 11.7 & 110 & 3.1 & 62.6 & 0.6 \\
\hline${ }^{*}$ Pseudospondias microcarpa & Anacardiaceae & $19,065.1$ & 4.0 & 38 & 2.5 & 32.1 & 9.0 \\
\hline Dictyandla sp. & Rubiaceae & 3031.5 & 18.8 & 177 & 2.4 & 71.7 & \\
\hline${ }^{*}$ Myrianthus holstii & Moraceae & 1078.9 & 20.0 & 188 & 2.3 & 32.8 & 2.1 \\
\hline Diospyros abyssinica & Ebenaceae & 6540.1 & 10.4 & 98.0 & 1.9 & 90.6 & \\
\hline Pleiocarpa pycnantha & Apocynaceae & 1681.8 & 14.8 & 139 & 1.8 & 8.4 & \\
\hline
\end{tabular}




\section{Continued}

\begin{tabular}{|c|c|c|c|c|c|c|c|}
\hline Fagaropsis angolensis & Rutaceae & 8133.5 & 7.3 & 69 & 1.7 & 7.3 & \\
\hline${ }^{*}$ Phyllanthus sp. & Euphobiacea & 8590.3 & 5.9 & 55 & 1.6 & 38.1 & - \\
\hline Neobtonia caccrocalyx & Euphorbiaceae & 4635.6 & 8.5 & 80 & 1.4 & 45.9 & \\
\hline "Bosquea phoberos & Moraceae & 1852.2 & 11.3 & 106 & 1.4 & - & Snr \\
\hline${ }^{*}$ Pavetta oliveriana & Rubiaceae & 4763.7 & 7.4 & 70 & 1.3 & 22.7 & 0.2 \\
\hline Macaranga kilimandscharica & Euphorbiaceae & 3412.7 & 7.4 & 70.0 & 1.2 & - & \\
\hline Baphiopsis parviflora & Leguminoceae & 1102.3 & 8.4 & 79 & 1.0 & - & \\
\hline Tabernaemontana holstii & Apocynaceae & 519.1 & 7.7 & 72 & 0.9 & 1.3 & \\
\hline Spathodea campanulata & Bignoniaceae & 2574.5 & 3.8 & 36 & 0.7 & 0.4 & \\
\hline${ }^{*}$ Chrysophyllum albidum & Sapotaceae & 4880.3 & 1.4 & 13 & 0.7 & 12.2 & 0.1 \\
\hline Belonophora hypoglauca & Rubiaceae & 867.4 & 5.5 & 52 & 0.7 & 2.7 & \\
\hline Polycius fulva & Araliaceae & 1716.7 & 3.7 & 35 & 0.6 & - & \\
\hline Entandrophragma excelsum & Meliaceae & 1005.7 & 4.3 & 40 & 0.6 & - & \\
\hline Crotony microstychus & Euphorbiaceae & 2644.0 & 3.3 & 31 & 0.6 & 7.1 & \\
\hline Cassipourea malosana & Rhizophoraceae & 615.9 & 3.8 & 36 & 0.5 & - & \\
\hline Ritchea alberthii & Epacridaceae & 1462.7 & 1.9 & 18 & 0.4 & 7.6 & \\
\hline Renorea illiciforia & Violaceae & 486.2 & 2.8 & 26 & 0.4 & 26.0 & \\
\hline Harungana madagascanensis & Guttiferecaea & 395.8 & 3.0 & 28.0 & 0.4 & - & \\
\hline Dovyalis zenkeri & Flacourtiaceae & 691.5 & 2.7 & 25 & 0.4 & 1.6 & \\
\hline Bersama abyssinica & Melianthaceae & 1538.2 & 2.0 & 19 & 0.4 & 3.5 & \\
\hline Albizia spp. & Leguminoceae & 1289.0 & 2.8 & 26 & 0.4 & 0.1 & \\
\hline${ }^{*}$ Vangueria apeculata & Rubiaceae & 516.0 & 3.0 & 28 & 0.4 & 8.1 & - \\
\hline${ }^{*}$ Teclea nobilis & Rutaceae & 249.2 & 2.7 & 25 & 0.3 & 17.4 & Snr \\
\hline Leptonechea mildbridii & Sterculiaceae & 159.6 & 2.1 & 20 & 0.3 & - & \\
\hline Gaurea cedrata & Meliaceae & 239.3 & 2.7 & 25 & 0.3 & - & \\
\hline Anthocleista grandiflora & Loganiaceae & 552.2 & 2.4 & 23 & 0.3 & - & \\
\hline Alangium chinense & Alangiaceae & 413.2 & 2.1 & 20 & 0.3 & 0.5 & \\
\hline Maesopsis emnii & Rhamaceae & 428.4 & 2.0 & 19 & 0.3 & - & \\
\hline${ }^{*}$ Antiaris toxicaria & Moraceae & 864.2 & 1.7 & 16 & 0.3 & 3.9 & 0.0 \\
\hline Vitex ferugeana & Verbanaaceae & 566.3 & 1.5 & 14 & 0.2 & 1.5 & \\
\hline Trichulia volukense & Meliaceae & 122.6 & 1.7 & 16 & 0.2 & 25.5 & \\
\hline Symphonia globurifera & Cluciacea & 1409.6 & 0.7 & 7 & 0.2 & 3.5 & \\
\hline Rothmania longiflora & Rubiaceae & 147.7 & 1.4 & 13 & 0.2 & 1.6 & \\
\hline Rauvolfia cafra & Apocynaceae & 259.2 & 1.4 & 13 & 0.2 & - & \\
\hline Phoenix reclinata & Arecaceae & 908.3 & 0.6 & 6 & 0.2 & 0.1 & \\
\hline Vernonia conferta & Asteraceae & 197.5 & 0.9 & 8 & 0.1 & - & \\
\hline Pancovia & Rosaceae & 52.2 & 0.4 & 4 & 0.1 & & \\
\hline Ochna membracae & Ochnaceae & 145.6 & 0.5 & 5 & 0.1 & 6.7 & \\
\hline Maesa lanceolata & Mycinaceae & 155.2 & 1.0 & 9 & 0.1 & - & \\
\hline Lindackeria schweinfurthii & Flacourtiaceae & 153.1 & 1.1 & 10 & 0.1 & - & \\
\hline Cordia africana & Boraginaceae & 1050.2 & 0.3 & 3 & 0.1 & 2.6 & \\
\hline Brideria micrantha & Euphorbiaceae & 153.5 & 0.6 & 6 & 0.1 & 4.0 & \\
\hline Agelaea pentagyna & Connaraceae & 53.4 & 0.5 & 5 & 0.1 & 116.3 & \\
\hline${ }^{*}$ Uvariopsis congoensis & Annonaceae & 155.9 & 1.1 & 10 & 0.1 & 5.3 & 1.4 \\
\hline
\end{tabular}




\begin{tabular}{|c|c|c|c|c|c|c|c|}
\hline \multicolumn{8}{|l|}{ Continued } \\
\hline${ }^{*}$ Monodora myristica & Annonaceae & 278.9 & 0.5 & 5 & 0.1 & 0.9 & 1.1 \\
\hline Warbughia ugandensis & Canellaceae & 105.6 & 0.2 & 2 & 0.0 & - & \\
\hline Terminalea & Combrataceae & 18.8 & 0.1 & 1 & 0.0 & - & \\
\hline Pavetta bagshawei & Rubiaceae & 40.4 & 0.1 & 1 & 0.0 & 22.7 & \\
\hline Mytenus accuminatta & Celastraceae & 14.1 & 0.1 & 1 & 0.0 & - & \\
\hline Monodora indica & Annonaceae & 24.2 & 0.2 & 2 & 0.0 & - & \\
\hline Erythrococca stoloziana & Euphorbiaceae & 25.5 & 0.2 & 2 & 0.0 & - & \\
\hline Canthium oligocarpum & Rubiacea & 12.4 & 0.1 & 1 & 0.0 & - & \\
\hline Canerium (Omubani) & Burseraceae & 86.1 & 0.1 & 1 & 0.0 & - & \\
\hline${ }^{*}$ Landolphia dawei & Apocynaceae & 0.0 & 0.0 & & 0.0 & 22 & 12.9 \\
\hline${ }^{*}$ Dasylepis eggelingii & Flacourtiaceae & 21.2 & 0.2 & 2 & 0.0 & 76.7 & 0.1 \\
\hline "Carisa edulis & Apocynaceae & 8.4 & 0.1 & 1 & 0.0 & 2.8 & Snr \\
\hline${ }^{*}$ Phytolacca dodecandra & Phytolacaceae & - & & & & - & Snr \\
\hline *Afromomum angustifolium & Zingiberaceae & - & & & & - & 19.6 \\
\hline
\end{tabular}

"Species whose fruit is eaten by chimpanzees; Snr: seeds not recorded in faeces but consumption confirmed by direct observation; -: Amounts not obtained; Values for Basal area and Density Ranks, and \% faecal sample with seed are only for species eaten by chimpanzees; Dominance for Sp = Basal area for Sp/Unit area sampled; Freq of Sp = No of sample plots with SP/No of plots; \%Relative Density for Sp (RD) = Density for Sp $\times 100 /$ density for all spp; \%Relative Dominance for Sp $(\mathrm{RDOM})=$ Dominance for $\mathrm{Sp} \times 100 /$ dominance for all spp; \%Relative freq for Sp $(\mathrm{RF})=\mathrm{freq}$ of $\mathrm{Sp} \times$ 100/freq values for all spp; Species Importance Value Index for Sp (SIVI) $=$ RD + RDOM + RF.

species, only 33 provide fruit that is palatable to the chimpanzees. This is about $26.3 \%$. Percent consumption (measured in terms of seed occurrence in faecal samples) was generally low, consumption being eaten more than $25 \%$ in only two species. Among the top twenty tree species with the highest Species Value Index, only eight species (40\%) provided fruit to the chimpanzees. Among them is Craterispermurm laurinum, Celtis durandii, Ficus spp., Musanga leoerrerae, Drypetes bipidensis, Beischmiedia ugandensis and Alchonea hitera.

\subsection{Fruit Phenology and Availability}

The fruit availability indices (FAI) of all species indicate that Celtis durandii produced most fruit followed by Strombosia scheffleri (Alocaceae) which produced 16\% of total fruit abundance (Table 2). Fruit monitoring produced different categories of fruiting phenology. Only major trees whose fruit were eaten by chimpanzees were monitored. The fruit trees exhibited different fruiting peaks. The presence of young and mature fruit of these species is shown in Figure 1. Generally most mature fruit was abundant in the rainy season, except for Afromomum angustifolium where the fruiting peak appears during the late dry season. There was almost no ripe fruit for Myrianthus holstii, and Drypetes bipidensis in the months of August and September. Pseudospondias microcarpa and Bielschimedia ugandensis did not fruit in March, January and November respectively. Amount of fruiting also varied between years and some trees like Bielschmiedia ugandensis were observed to fruit once in the two years. Musanga leo-errerae and Ficus spp showed perennial fruiting. For purposes of illustration, phenologies of the six ficus species (Ficus sur, Ficus thoningii, Ficus saussreana, Ficus vallis choudae, Ficus bubu and Ficus natalensis) that were monitored are combined and taken as one species group. The highest diversity in fruiting of trees eaten by chimpanzees was recorded in the short (January-February) and the long rainy season (September-December). There was a positive correlation between fruiting and rainfall within Kalinzu Forest Reserve $(\mathrm{r}=0.603 ; \mathrm{P}=0.008)$.

\subsection{Seasonality in Fruit Availability and Consumption}

Availability of fruit eaten by chimpanzee fluctuated both monthly and seasonally and so did the frequency of occurrence of fruit seed in chimpanzee faeces. After the analysis of 2635 faecal samples, seeds of 33 fruit species were identified. Of these, five species were found in very minimal amounts in chimpanzee diet. These include Vangueria apiculata, Alchonea hitera, Antiaris toxicaria, Fagaropsis angolensis and Syzigium guinense. The trees that produced the largest crop of fruit like Celtis durandii and Craterispermum laurinum did not occur 


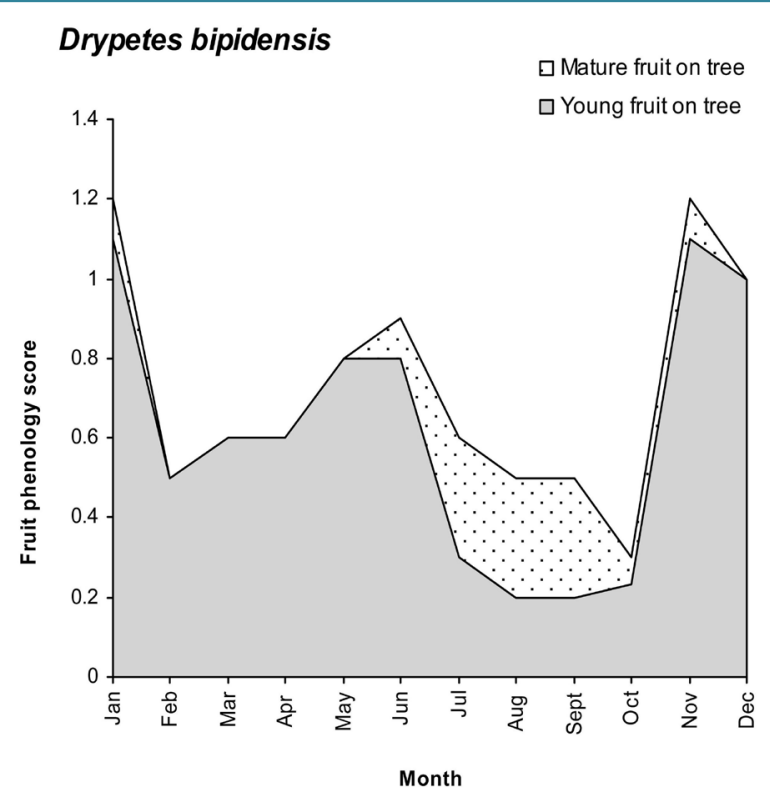

Myrianthus holstii

$\square$ Mature fruit on tree $\square$ Young fruit on tree

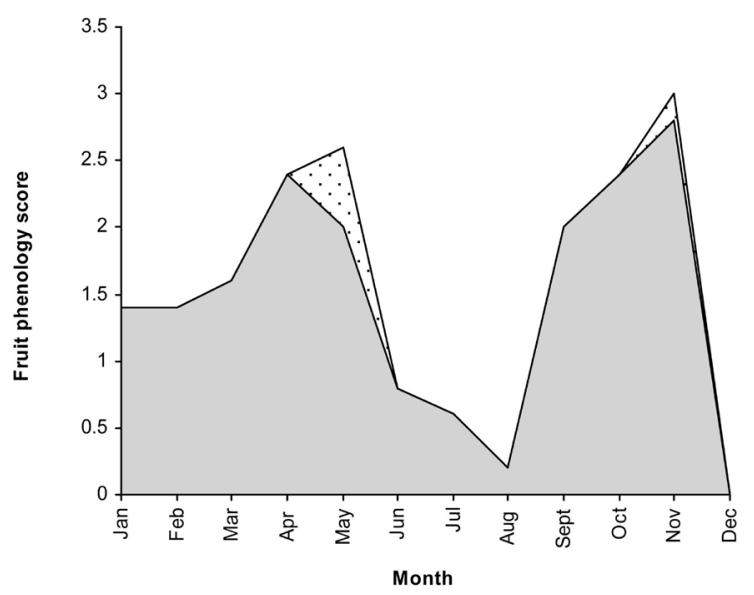

Afromomum angustifolium

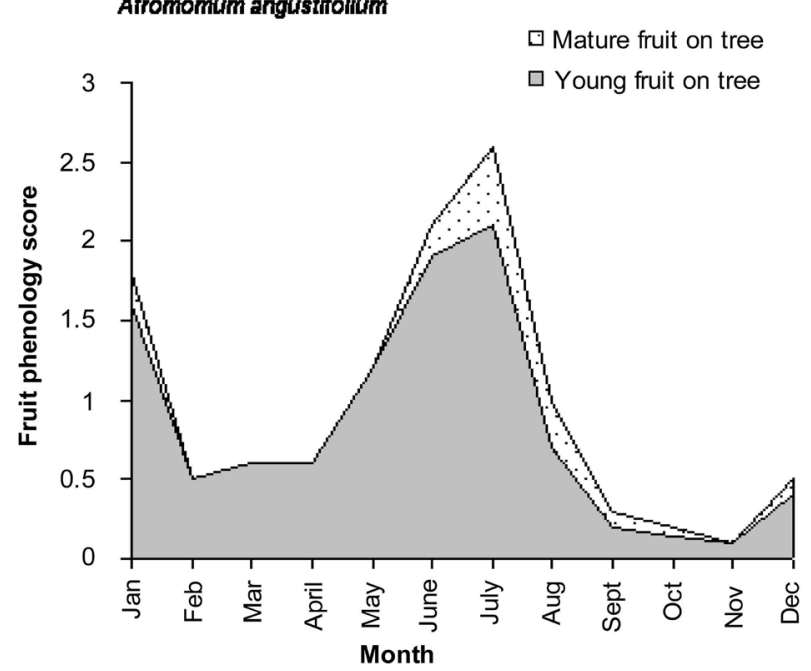

\section{Pseudospondius microcarpa}

$\square$ Mature fruit on tree

$\square$ Young fruit on tree

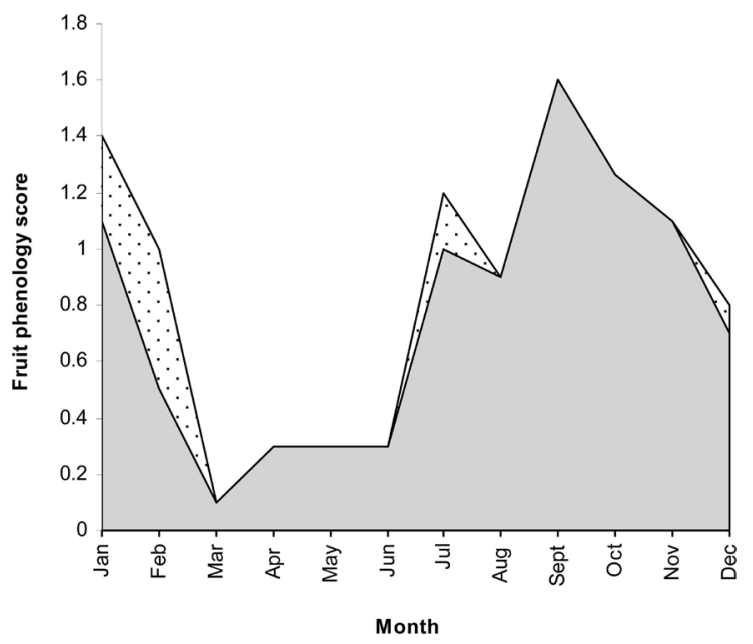

Bielschmiedia ugandensis

$\square$ Mature fruit on tree

$\square$ Young fruit on tree

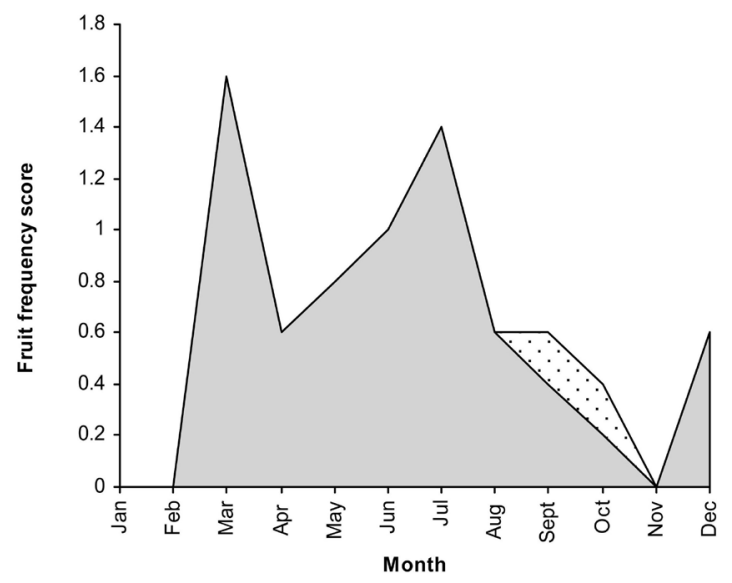

Ficus species

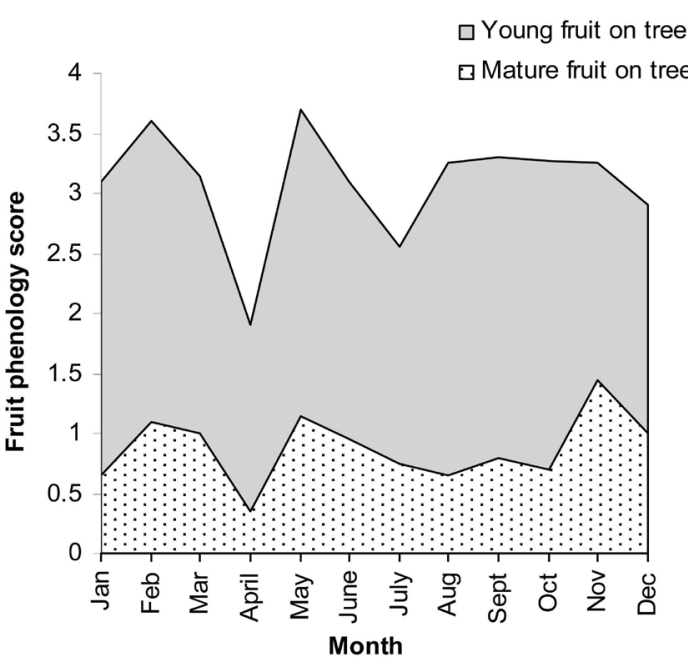




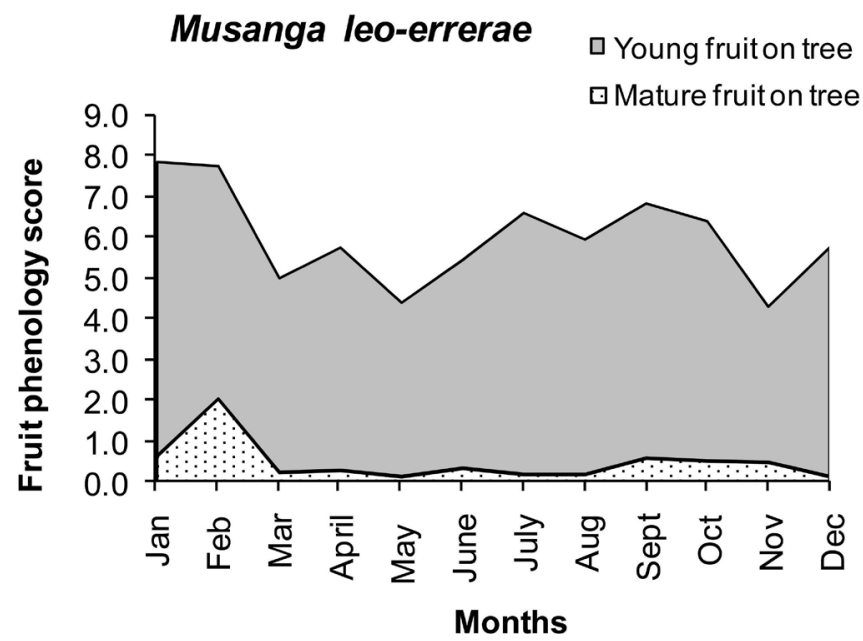

Figure 1. Continued (fruiting phenology of seasonal fruit trees eaten by chimpanzees).

prominently in chimpanzee diet. Craterispermum laurinum fruits however supplemented chimpanzee diet for two months during the dry season (period of scarcity). The tree species, whose fruit were eaten in greater amounts and frequencies, had medium fruit abundance. Musanga and Ficus species occurred in faeces all year round. Myrianthus holstii, Afromomum angustifolium, Landolphia dawei, Pseudospondias microcarpa, Mimusops kummel and Uvariopsis congensis occurred in faeces in the rainy season. Celtis durandii, Beilschmiedia ugandensis, Drypetes bipidensis and Phytolacca dodecandra occurred in mid season between the rainy and dry seasons. Craterispermurm laurinum and Monodora myristica's occurrence in faecal samples coincided exactly with their availability during the dry season.

The occurrence of seeds of some fruit species in chimpanzee faeces was positively correlated with their availability in the habitat. These included Myrianthus holstii, Uvariopsis congensis, Monodora myristica, Bielschmiedia ugandensis, Landolphia dawei and Craterispermum laurinum, suggesting that these fruits were consumed as they were available. This correlation was however significant only for Landolphia dawei. The monthly mean of fruit availability index of Musanga leo-errerae, Drypetes bipidensis, Pseudospondias microcarpa, Ficus spp. and Celtis durandii did not correlate with their monthly frequency in chimpanzee faeces. Only tree species were considered in this analysis, therefore fruits of Afromomum angustifolium (herb) and Phytolacca dodecandra (shrub) were not included in this analysis (Figure 2).

\section{Discussion}

Tree species diversity and production associated with high altitudes have been documented to be low [30]. Kalinzu forest has a medium altitude that is between montane and lowland categories. This may explain the lower density of tree species whose fruit is eaten by chimpanzees in Kalinzu than other forests at lower altitudes. Of the total 118 recorded species only 33 (26.3\%) were recorded to be eaten by chimpanzees. Of these 33, only two species were eaten in percentage abundance of more than $25 \%$. This shows that about $1.7 \%$ of woody biodiversity supports chimpanzees in terms of diet Kalinzu forest. The same trend occurs worldwide. According to [31] and [32] less than $1 \%$ of the plant diversity in the tropics sustains almost all frugivore communities. Therefore there is an urgent need to sustainably maintain and improve the already existing food source for the endangered chimpanzees and other endangered frugivorous species of the tropics.

Human beings through their various forms of forest utilisation are one of the factors that can affect tropical forest reproductive patterns. One of such utilisations is logging. Despite the continued logging, the top timber forest species still greatly dominate in Kalinzu forest. The tree species whose fruits are eaten by chimpanzees are poor in terms of timber provision; therefore cutting of timber species would not affect chimpanzees greatly in terms of food availability. Timber harvesting leads to creation of gaps that cause colonisation of secondary tree species that are important sources of food for chimpanzees. Secondary vegetation may certainly help chimpanzee survival because of the high density of important foods such as Terrestrial Herbaceous Vegetation (THV), Ficus and Musanga genera [23] [33] [34]. In Budongo, however, there was no evidence that chimpanzees 


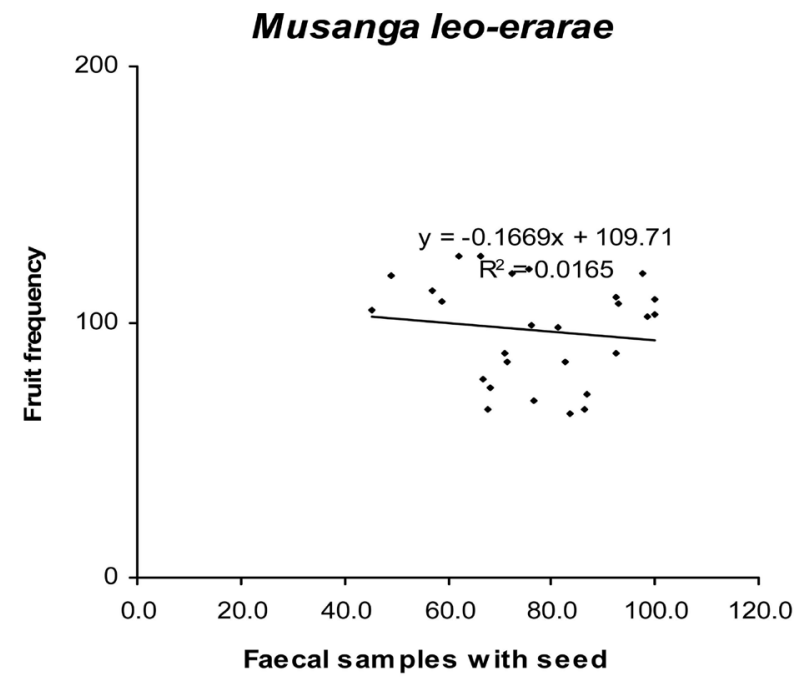

Landolphia dawei

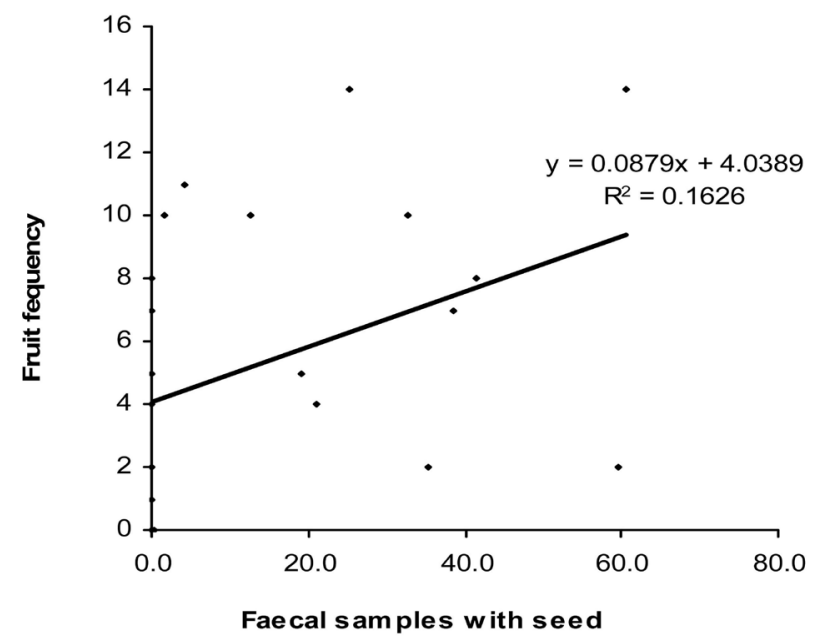

\section{Craterispermum laurinum}

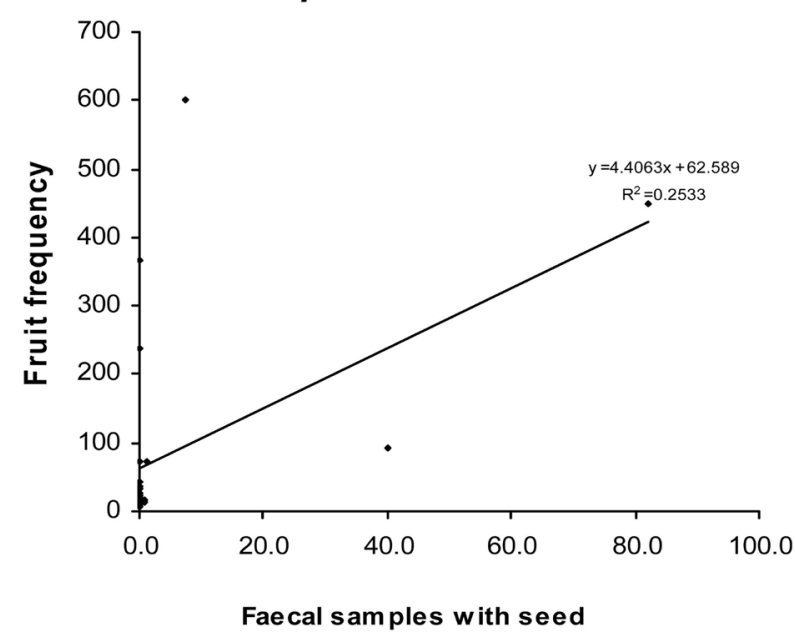

Ficus sp

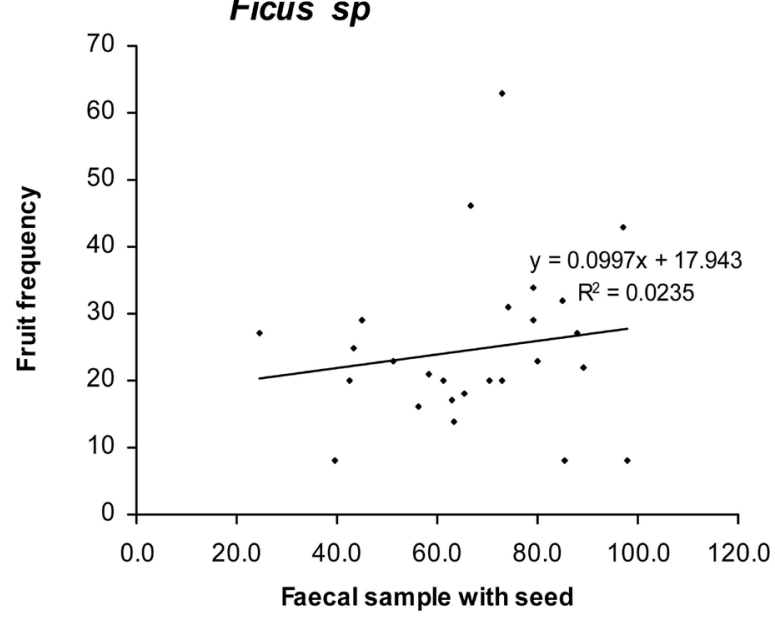

Bielshmiedia ugandensis
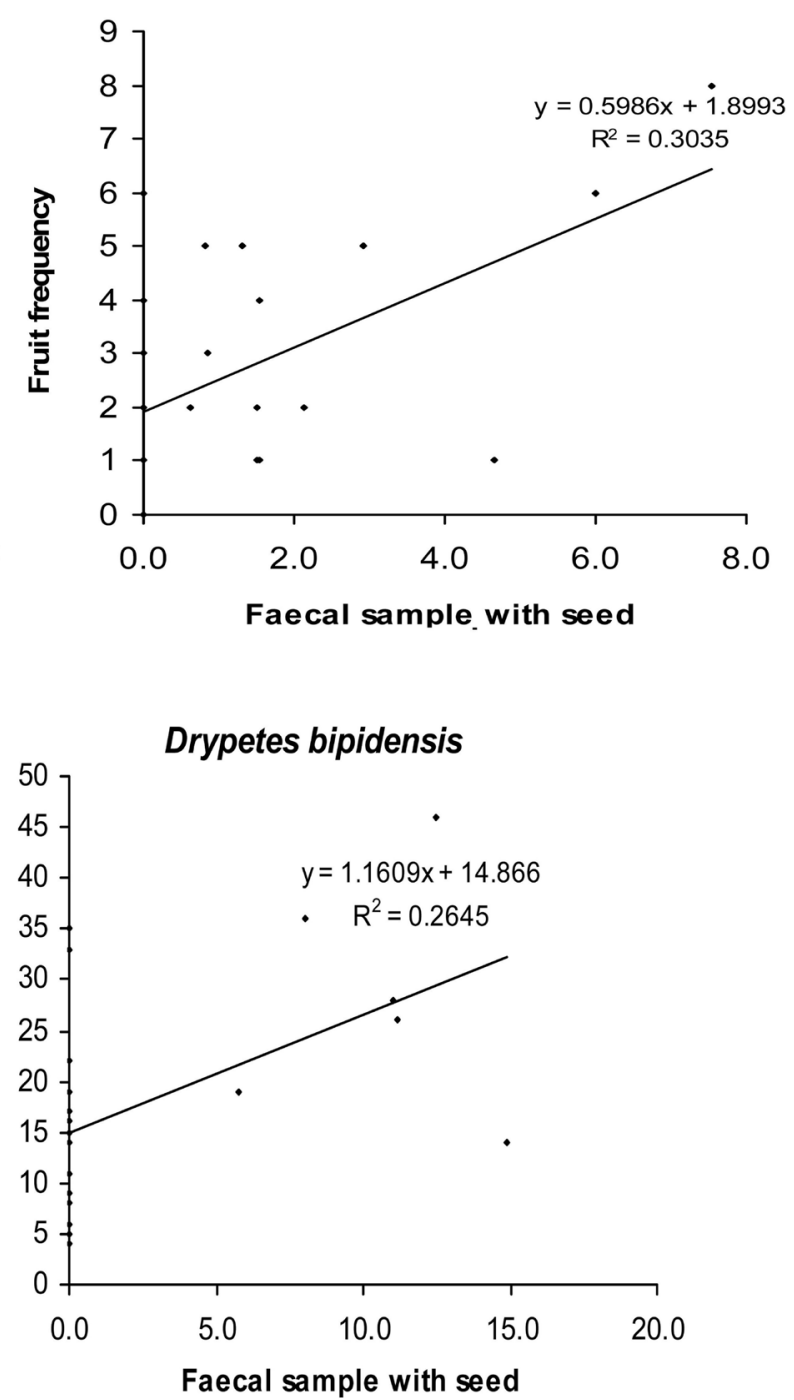

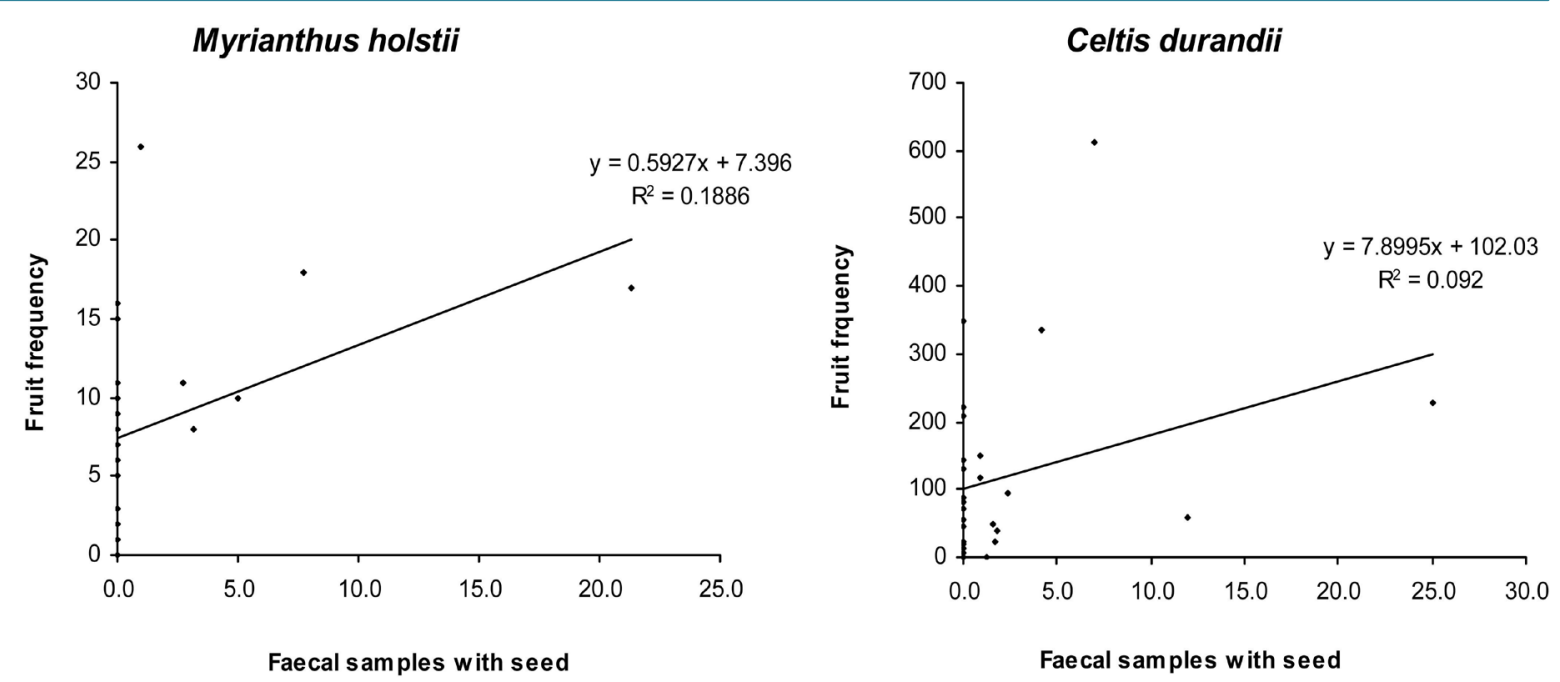

Peudospondius microcarpa

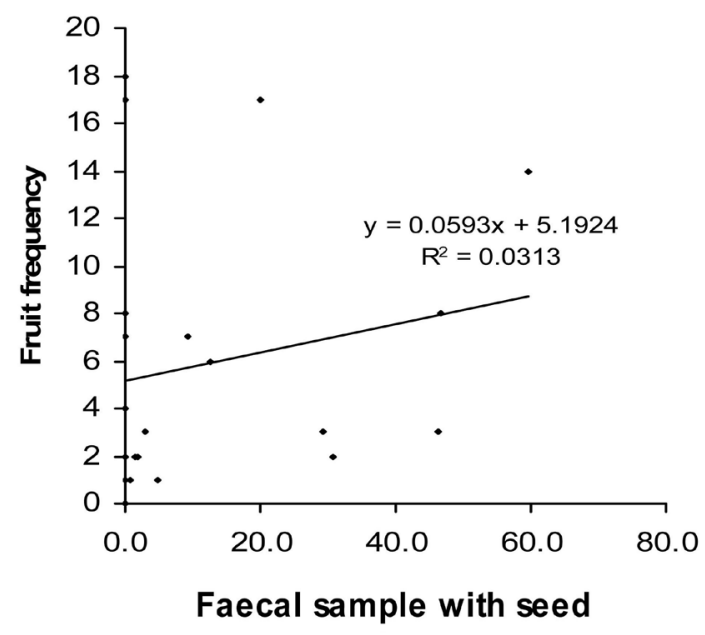

Monodora Myristica
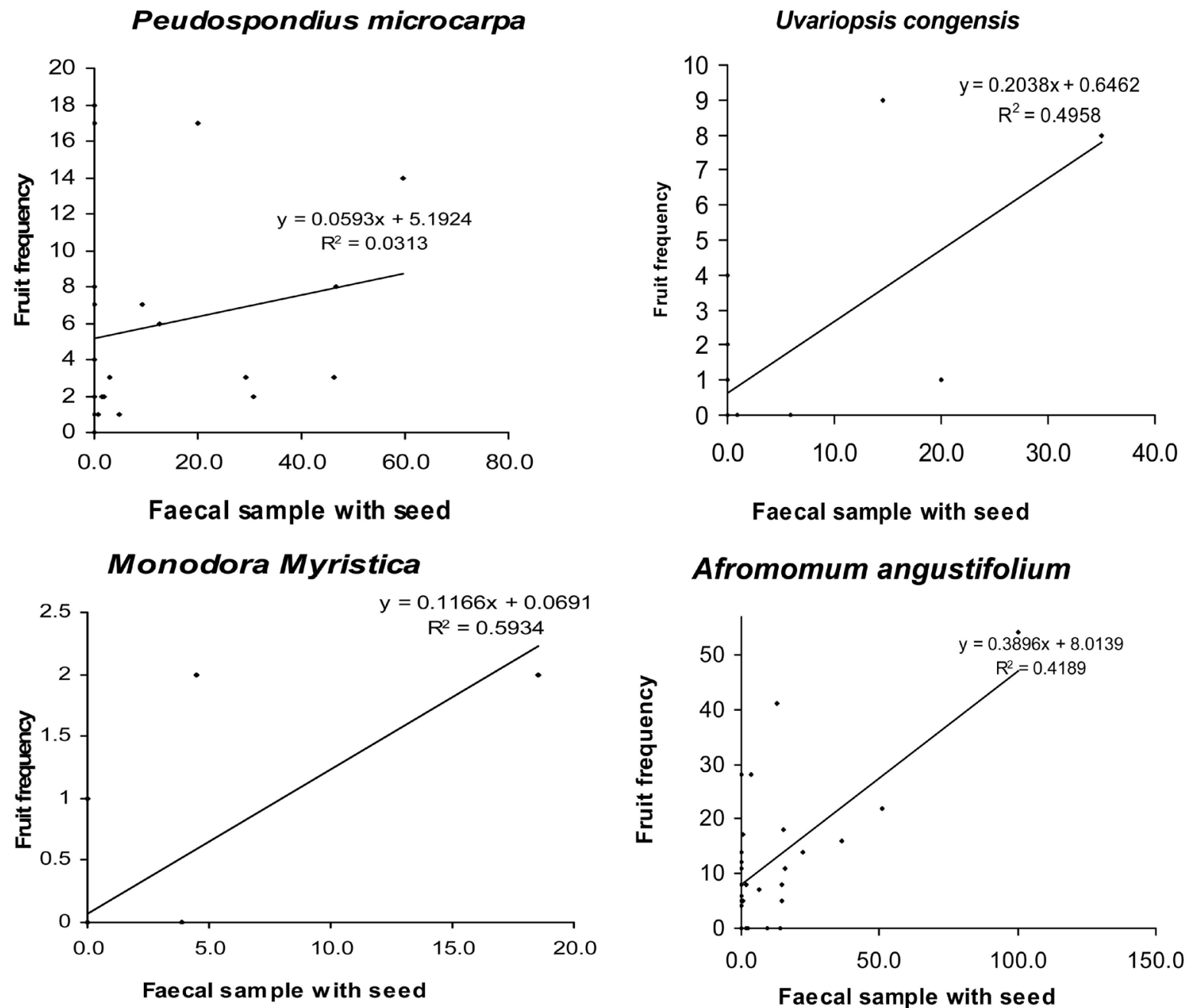

\section{Afromomum angustifolium}

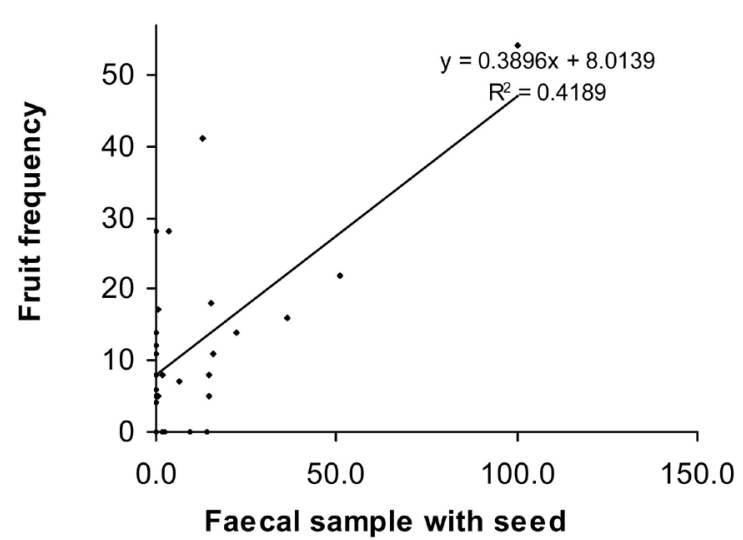

Figure 2. Correlation between FAI and presence of major fruit species in chimpanzee faeces.

benefited from logging, although some other primates did [35]. In Kibale, the density of chimpanzees was significantly lower in the logged plot [36] [37]. In Kalinzu, the chimpanzee density was very low in the Parinari secondary forest, although the density in the Musanga secondary forest was high. It is indicated that where log- 
ging has taken place, the density of chimpanzees is often lower than that in mature undisturbed forests [35] [37]. The value of secondary vegetation may therefore depend on the original vegetation type, the manner and frequency of logging and time elapsed since latest logging.

Logging is one form of disturbance that affects fruiting patterns in tropical forests because it alters the microhabitat and distribution of conspecific trees, consequently influencing fruit and seed production [38]. Duration, frequency and intervals of fruiting episodes also differ among trees of different successional status. Pioneer species produce fruit every year and have extended fruiting periods. In contrast, primary forest species have irregular fruiting periods and sometimes experience masting. Masting, a phenomenon in which synchronous reproduction within a plant in one year is followed by an interval in which few or no fruits are produced was not seen in Kalinzu. Some of the primary forest fruit species eaten by chimpanzee like Beilschmiedia ugandensis and Pseudospondius microcarpa showed only one peak of fruit production during the long rainy season. Craterispermum laurinum and Monodora myristica were uni-modal and important for the chimpanzees in the dry season. Uvariopsis congensis was unimodal and fruited during the long wet season. Therefore, different fruit species have different seasons of fruiting and the interval period between fruiting cycles differ from species to species. Musanga leo-errerae and most of the Ficus sp. (except Ficus natalensis), on which chimpanzees depended mostly, did not show marked seasonality. There was however an increase of fruit production of both genera with increase in rainfall. The continued occurrence of the fruit of Ficus species can be explained by the presence of aganoid wasps responsible for pollination in Ficus species [39]. This ensures all year round production of fruit. When one species/tree is running out of fruit, another starts ripening while another has immature fruits and others flowering. Ficus sur had three high peaks of fruit production and short-lived low peaks which meant an almost continued existence of this fruit throughout the year [40]. Fruiting among other major figs was largely bimodal. Similarly, in Budongo, the availability of figs was important especially in the dry season, because other fruiting trees tended to have fruits in the wet season [41]. Figs were also important for chimpanzee social interaction because they have wide canopies and produce large crops when in fruit [42]. Figs that occurred in Budongo also occur in Kalinzu except Ficus mucuso, Ficus varifolia, Ficus asperlifolia and Ficus polita. F. mucuso and F. varifolia have 2 - 3 years interval [40] without any fruit production and similar findings were recorded in other tropical forests. These could therefore have not accounted for major differences in Ficus fruit availability if they were present in Kalinzu forest. In Musanga, the type of inflorescence ensures continued growth and production of fruit throughout the year as the preliminary study by [43] also documented. The ants of genus Azeteca found in the internodes of Musanga stem may also play a big role in pollination.

General fruiting patterns were distinctly seasonal, with different peaks in both ripe and unripe fruit production. In most lowland tropical rain forests, there is seasonal variation in the phenological patterns of tree species during the annual cycle [44]. Factors including temperature, rainfall, humidity levels, and day length were found to be important in determining such patterns [45]-[48]. In Kalinzu forest, a higher number of species fruited during the wet season than during the dry season indicating that rainfall is one of the major factors that influence fruiting. This was also indicated by [49] that the monthly number of species that fruited in each forest condition was significantly related to monthly rainfall. The tree species whose fruit were eaten by chimpanzees during the wet season did not greatly influence fruit abundance. Chimpanzees relied on them when they are abundant, but they did not play a significant role since the difference between periods of abundance and periods of scarcity as a result of fruiting in wet season was small. Similar seasonal patterns in plant production in Kibale forest with almost same altitude as Kalinzu and where climate is similarly seasonal were documented [44]. The lack of correlation between fruit availability index and occurrence of fruit seed in faeces of some species suggests that chimpanzees are not opportunistic feeders, and they actively search for these fruits.

Fruit production of trees constitutes the major food sources for frugivorous primates, and its abundance and seasonal availability may have great influences on the density of these primates [50]. On the other hand, a combination of various types of trees with both seasonal and annual fruiting may certainly benefit chimpanzees [51] [52]. Therefore the pattern and length of the fruiting period of these species play an important role in survival of chimpanzees in Kalinzu where only a limited number of species offer ripe fruit at the same time in both the dry and the long rainy seasons. Chimpanzees have been documented to range most in areas of high fruiting and in areas with important foods especially during fruit scarcity [53] [54]. This means that chimpanzees range furthest during fruit scarcity in search of food that is not readily available. Fruit availability is therefore important in the conservation of chimpanzees in terms of energy costs during fruit search. With abundant availability of fruit, chimpanzees will range less and conserve energy. 


\section{Acknowledgements}

This field work was facilitated by ground work done by Assistant Professor Chie Hashimoto and the Ugandan staff of the Kalinzu forest project. We thank the Administration of Mbarara University for granting us time to do the research. This research was financed by the Kalinzu Forest Project and Deutscher Akademischer Austausch Dienst (DAAD) awarded to Grace Kagoro Rugunda (No. A/03/15191), to them we are very grateful.

\section{References}

[1] Furuichi, T., Hashimoto, C. and Tashiro, Y. (2001) Seasonal Changes in Habitat Use by Chimpanzees in the Kalinzu Forest, Uganda: Extended Application of Marked Nest Census Method. International Journal of Primatology, 22, 913928. http://dx.doi.org/10.1023/A:1012057403512

[2] Kuroda, S., Nishihara, T., Suzuki, S. and Oko, R.A. (1996) Sympatric Chimpanzees and Gorilla in the Ndoki Forest, Congo. In: Mcgrew, W.C., Merchant, L.F. and Nishida, T., Eds., Grape Ape Societies, Cambridge University Press, Cambridge, 71-81. http://dx.doi.org/10.1017/cbo9780511752414.008

[3] Remis, M.J. (1997) Ranging and Grouping Patterns of a Western Lowland Gorilla Group at Bai Hokou, Central African Republic. American Journal of Primatology, 43, 111-133. http://dx.doi.org/10.1002/(SICI)1098-2345(1997)43:2<111::AID-AJP2>3.0.CO;2-\#

[4] Tutin, C.E.G., Ham, R.M., White, L.J.T. and Harrison, M.J.S. (1997) The Primate Community of the Lopé Reserve, Gabon: Diets, Responses to Fruit Scarcity, and Effects on Biomass. American Journal of Primatology, 42, 1-24. http://dx.doi.org/10.1002/(SICI)1098-2345(1997)42:1<1::AID-AJP1>3.0.CO;2-0

[5] Basabose, A.K. (2002) Diet Composition of Chimpanzees Inhabiting the Montane Forest of Kahuzi, Democratic Republic of Congo. American Journal of Primatology, 58, 1-21. http://dx.doi.org/10.1002/ajp.10049

[6] Remis, M.J. (1997) Western Lowland Gorillas (Gorilla gorilla gorilla) as Seasonal Frugivores: Use of Variable Resources. American Journal of Primatology, 43, 87-109. http://dx.doi.org/10.1002/(SICI)1098-2345(1997)43:2<87::AID-AJP1>3.0.CO;2-T

[7] Basabose, A.K. (2005) Ranging Patterns of Chimpanzees in a Montane Forest of Kahuzi, Democratic Republic of Congo. International Journal of Primatology, 26, 33-54. http://dx.doi.org/10.1007/s10764-005-0722-1

[8] Yamagiwa, J. and Basabose, A.K. (2006) Diet and Seasonal Changes in Sympatric Gorillas and Chimpanzees at Kahuzi-Biega National Park. Primates, 47, 74-90. http://dx.doi.org/10.1007/s10329-005-0147-7

[9] Hashimoto, C., Suzuki, S., Takenoshita, Y., Yamagiwa, J., Basabose, A.K. and Furuichi, T. (2003) How Fruit Abundance Affects the Chimpanzee Party Size: A Comparison between Four Study Sites. Primates, 44, 77-81.

[10] Basabose, A.K. (2004) Fruit Availability and Chimpanzee Party Size at Kahuzi Montane Forest, Democratic Republic of Congo. Primates, 45, 211-219. http://dx.doi.org/10.1007/s10329-004-0087-7

[11] Anderson, D.P., Nordheim, E.V. and Boesch, C. (2006) Environmental Factors Influencing the Seasonality of Estrus in Chimpanzees. Primates, 47, 43-50. http://dx.doi.org/10.1007/s10329-005-0143-y

[12] Itoh, N. and Nishida, T. (2007) Chimpanzee Grouping Patterns and Food Availability in Mahale Mountains National Park, Tanzania. Primates, 48, 87-96. http://dx.doi.org/10.1007/s10329-006-0031-0

[13] Yamkoshi, G. (1998) Dietary Responses to Fruit Scarcity of Wild Chimpanzees at Bossou, Guinea: Possible Implications for Ecological Importance of Tool Use. American Journal of Physical Anthropology, 106, 283-295. http://dx.doi.org/10.1002/(SICI)1096-8644(199807)106:3<283::AID-AJPA2>3.0.CO;2-O

[14] Terborgh, J. (1986) Keystone Plant Resources in the Tropical Forest. In: Soulé, I. and Michael, E., Eds., Conservation Biology, Sinauer, Sunderland, 330-344.

[15] Doran, D.M., Mcneilage, A., Greer, D., Bocian, C., Mehlman, P. and Shah, N. (2002) Western Lowland Gorilla Diet and Resource Availability: New Evidence, Cross-Site Comparisons, and Reactions on Indirect Sampling Methods. American Journal of Primatology, 58, 91-116. http://dx.doi.org/10.1002/ajp.10053

[16] Turner, L.A. (2006) Vegetation and Chimpanzee Ranging in the Mahale Mountains National Park, Tanzania. Memories of the Faculty of Science, Kyoto University, 18, 45-82.

[17] Chapman, C.A., Wrangham, R.W., Chapman, L.J., Kennard, D.K. and Zanne, A.E. (1999) Fruit and Flower Phenology at Two Sites in Kibale National Park, Uganda. Journal of Tropical Ecology, 15, 189-211. http://dx.doi.org/10.1017/S0266467499000759

[18] Tweheyo, M. and Babweteera, F. (2007) Production, Seasonality and Management of Chimpanzee Food Trees in Budongo Forest, Uganda. African Journal of Ecology, 45, 535-544. http://dx.doi.org/10.1111/j.1365-2028.2007.00765.x

[19] Anderson, D.P., Nordheim, E.V., Moermond, T.C., Gone Bi, Z.B. and Boesch, C. (2005) Factors Influencing Tree Phenology in Taï National Park, Cotê d’Ivore. Biotropica, 37, 631-640. 
http://dx.doi.org/10.1111/j.1744-7429.2005.00080.x

[20] Leighton, M. and Leighton, D.R. (1983) Vertebrate Responses to Fruiting Seasonality within a Bornean Rain Forest. In: Whitmore, S.T.C. and Chadwick, A.C., Eds., Tropical Rain Forest: Ecology and Management, Volume 2, Blackwell Scientific Publications, Palo, 181-196.

[21] Struhsaker, T.T. (1976) A Further Decline in Numbers of Amboseli Vervet Monkeys. Biotropica, 8, 211-214. http://dx.doi.org/10.2307/2989688

[22] Dittus, W.P. (1977) The Social Regulations of Population Density and Sex-Age Distributions in the Torque Monkey. Behaviour, 63, 281-322. http://dx.doi.org/10.1163/156853977X00450

[23] Hashimoto, C., Furuichi, T. and Tashiro, Y. (1999) Diversity in Forest Types and Habitat Use by Chimpanzees in the Kalinzu Forest, Uganda. Primate Research, 15, 129-134. http://dx.doi.org/10.2354/psj.15.129

[24] Hashimoto, C., Furuichi, T. and Tashiro, Y. (1999) Vegetation of the Kalinzu Forest Uganda: Ordination of Forest Types Using Principal Component Analysis. African Study Monographs, 20, 229-239.

[25] Newstrom, L.E., Frankie, G.W. and Baker, H.G. (1994) A New Classification for Plant Phenology Based on Flowering Plants in Lowland Tropical Rainforest Trees at La Selva, Costa Rica. Biotropica, 26, 141-159. http://dx.doi.org/10.2307/2388804

[26] Plumptre, A.J., Cox, D. and Mugume, S. (2003) The Status of Chimpanzees in Uganda. Albertine Rift Technical Report Series No. 2, Wildlife Conservation Society, New York.

[27] Howard, P.C. (1991) Nature Conservation in Uganda’s Tropical Forest Reserves. IUCN, Gland, Switzerland and Cambridge.

[28] Hashimoto, C. (1999) Observations on the Injuries Sustained by Wild Chimpanzees in the Kalinzu Forest, Uganda. Primate Research, 15, 187-192. http://dx.doi.org/10.2354/psj.15.187

[29] Kindt, R. and Coe, R. (2005) Tree Diversity Analysis. A Manual and Software for Common Statistical Methods for Ecological and Biodiversity Studies. World Agroforestry Centre (ICRAF), Nairobi.

[30] Yamayigwa, J., Kaleme, K., Milinganyo, M. and Babose, K. (1996) Food Density and Ranging Patterns of Gorillas and Chimpanzees in the Kahuzi-Biega National Park, Zaire. Tropics, 6, 65-77. http://dx.doi.org/10.3759/tropics.6.65

[31] Hladik, C.M. (1977) Chimpanzees of Gabon and Chimpanzees of Gombe: Some Comparative Data on the Diet. In: Clutton-Brock, T.H., Ed., Primate Ecology, Academic Press, New York, 481-501.

[32] Terborgh, J. (1983) A Method of Sitting Parks and Reserves with Special Reference to Colombia and Ecuador. Biological Conservation, 19, 45-58. http://dx.doi.org/10.1016/0006-3207(83)90005-8

[33] White, L.J.T. (1994) Patterns of Fruit-Fall Phenology in the Lopé Reserve, Gabon. Journal of Tropical Ecology, 10, 289-312. http://dx.doi.org/10.1017/S0266467400007975

[34] Wrangham, R.W., Chapman, C.A., Clark-Arcadi, A.P. and Isabirye-Basuta, G. (1996) Social Ecology of Kanyawara Chimpanzees: Implications for Understanding the Costs of Great Ape Groups. In: McGrew, W.C., Merchant, L.F. and Nishida, T., Eds., Great Ape Societies, Cambridge University Press, Cambridge, 45-57. http://dx.doi.org/10.1017/CBO9780511752414.006

[35] Plumptre, A.J. and Reynolds, V. (1994) The Impact of Logging on the Primate Populations in the Budongo Forest Reserve, Uganda. Journal of Applied Ecology, 31, 631-641. http://dx.doi.org/10.2307/2404154

[36] Skorupa, J.P. (1986) Responses of Rain Forest Primates to Selective Logging in Kibale Forest, Uganda: A Summary Report. In: Benirschke, K., Ed., Primates: The Road to Self Sustaining Populations, Springer-Verlag, Berlin, 57-70. http://dx.doi.org/10.1007/978-1-4612-4918-4 6

[37] Struhsaker, T.T. (1997) Ecology of an African Rainforest, Logging in Kibale and the Conflict between Conservation and Exploitation. University Press of Florida, Florida.

[38] Bawa, K.S. and Ng, F.S. (1990) Plant Phenology-A Commentary. In: Bawa, K.S. and Hadley, M., Eds., Reproductive Ecology of Tropical Forest Plants, UNESCO and Panthenon Publishing Group, London, 17-20.

[39] Janzen, D.H. (1979) How to Be a Fig. Annual Review of Ecology and Systematics, 10, 13-51. http://dx.doi.org/10.1146/annurev.es.10.110179.000305

[40] Tweheyo, M. and Lye, K.A. (2003) Phenology of Figs in Budongo Forest Uganda and Its Importance for the Chimpanzee Diet. African Journal of Ecology, 41, 306-316. http://dx.doi.org/10.1111/j.1365-2028.2003.00475.x

[41] Plumptre, A.J. and Reynolds, V. (1997) Nesting Behaviour of Chimpanzees: Implications for Censuses. International Journal of Primatology, 18, 475-485. http://dx.doi.org/10.1023/A:1026302920674

[42] Tweheyo, M. and Obua, J. (2001) Feeding Habits of Chimpanzees (Pan troglodytes), Red-Tail Monkeys (Cercopithecus ascanius schemdti) and Blue Monkeys (Cercopithecus mitis stuhlmanii) on Figs in Budongo Forest Reserve, Uganda. African Journal of Ecology, 39, 133-139. http://dx.doi.org/10.1046/j.1365-2028.2001.00290.x 
[43] Hashimoto, C., Furuichi, T. and Tashiro, Y. (2001) Fruit Availability and Habitat Use by Chimpanzees in the Kalinzu Forest, Uganda: Examination of Fall Back Foods. International Journal of Primatology, 22, 929-945. http://dx.doi.org/10.1023/A:1012061504420

[44] Chapman, C.A., White, F.J. and Wrangham, R.W. (1994) Party Size in Chimpanzees and Bonobos. In: Wrangham, R.W., McGew, W.C., de Waal, F.B.M. and Holte, P.G., Eds., Chimpanzee Cultures, Harvard University Press, Cambridge, MA and London, 41-57.

[45] Tutin, C.E.G. and Fernandez, M. (1993) Composition of Diet of Chimpanzees and Comparisons with That of Sympatric Lowland Gorillas in the Lope Reserve, Gabon. American Journal of Primatology, 30, 195-211. http://dx.doi.org/10.1002/ajp.1350300305

[46] Kinnard, F.M. (1992) Phenology of Flowering and Fruiting of an East African Riverine Forest Ecosystem. Biotropica, 24, 187-194. http://dx.doi.org/10.2307/2388672

[47] Peres, C.A. (1994) Primate Responses to Phenological Changes in an Amazonian Terra Firme Forest. Biotropica, 26, 98-112. http://dx.doi.org/10.2307/2389114

[48] Machado, I.C.S., Barros, L.M. and Sampaio, E.V.S.B. (1997) Phenology of Caatinga Species at Serra Talhada, PE, Northeastern Brazil. Biotropica, 29, 57-68. http://dx.doi.org/10.1111/j.1744-7429.1997.tb00006.x

[49] Muhanguzi, H.D.R., Obua, J., Oryem-Origa, H. and Vetaas, O.R. (2003) Tree Fruiting Phenology in Kalinzu Forest, Uganda. African Journal of Ecology, 41, 171-178. http://dx.doi.org/10.1046/j.1365-2028.2003.00431.x

[50] Oates, J.F., Whitesides, G.H., Waterman, P.G., Green, S.M., Dasilva, G.L. and Mole, S. (1990) Determinants of Variation in Tropical Rain Forest Primate Biomass: New Evidence from West Africa. Ecology, 71, 328-343. http://dx.doi.org/10.2307/1940272

[51] Thomas, S.C. (1991) Population Densities and Pattern of Habitat Use among Anthropoid Primates of the Ituri Forest Zaire. Biotropica, 23, 68-83. http://dx.doi.org/10.2307/2388690

[52] White, L.J.T., Rogers, M.E., Tutin, C.E.G., Williamson, E.A. and Fernandez, M. (1995) Herbacious Vegetation in Different Forest Types in Lope Reseve, Gabon: Implications for Key Stone Food Availability. African Journal of Ecology, 33, 124-141. http://dx.doi.org/10.1111/j.1365-2028.1995.tb00788.x

[53] Hashimoto, C., Tashiro, Y., Kimura, D., Enomoto, T., Ingmanson, E.J., Idan, G. and Furuichi, T. (1998) Habitat Use and Ranging of Wild Bonobos (Pan paniscus) at Wamba. International Journal of Primatology, 19, 1045-1060. http://dx.doi.org/10.1023/A:1020378320913

[54] Moscovice, L.R., Issa, M.H., Petrzelkova, K.J., Keuler, N.S., Snowdon, C.T. and Huffman, M.A. (2007) Fruit Availability, Chimpanzee Diet, and Grouping Patterns on Rubondo Island, Tanzania. American Journal of Primatology, 69, 487-502. http://dx.doi.org/10.1002/ajp.20350 